\title{
Cydianerus latruncularius (Coleoptera: Curculionidae) damaging trumpet trees leaves (Handroanthus spp., Bignoniaceae) in Brasília, Brazil
}

\author{
Marcelo Tavares de Castro ${ }^{1}$ (D), Sandro Coelho Linhares Montalvão² (D), Rose Gomes Monnerat² (D), Dalva Luiz de Queiroz ${ }^{3 *}$ (DD \\ ${ }^{1}$ Centro Universitário ICESP de Brasília, Departamento de Agronomia, QS 05, Rua 300, Lote 01, CEP 71961-540, Brasília, DF, Brazil \\ ${ }^{2}$ Embrapa Recursos Genéticos e Biotecnologia, Laboratório de Bactérias Entomopatogênicas, Av. W5 Norte, C.P. 02372, CEP 70770-917, Brasília, DF, Brazil \\ ${ }^{3}$ Embrapa Florestas, Estrada da Riberia, km 111, C.P. 319, CEP 83411-000, Colombo, PR, Brazil
}

"Corresponding author:

dalva.queiroz@embrapa.br

Index terms:

Forest entomology

Weevil

Phytophagous insect

Termos para indexação:

Entomologia florestal

Gorgulho

Inseto fitófago

Received in 03/03/2020

Accepted in 30/10/2020

Published in 30/06/2021

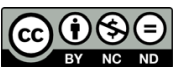

\begin{abstract}
Cydianerus latruncularius Perty (Coleoptera: Curculionidae) were observed associated with trumpet trees (Handroanthus spp.) in Brasília, Brazil, in 2019. To contribute with information about their habits and damage, 15 trees (Handroanthus impetiginosus $=7$, H. roseoalbus $=4$, and Tabebuia rosea $=4$ ) were evaluated and 31 individuals of $C$. latruncularius were captured, often found within or close to leaf rolls caused by the psyllid Trioza tabebuiae Burckhardt \& Santana (Hemiptera: Triozidae). The damage caused by C. latruncularius consists of irregular injuries at the leaves' edges. This is the first report of this beetle occurring on trumpet trees.
\end{abstract}

\section{Cydianerus latruncularius (Coleoptera: Curculionidae) danificando folhas de ipês (Handroanthus spp., Bignoniaceae) em Brasília, Brasil}

\begin{abstract}
Resumo - Cydianerus latruncularius Perty (Coleoptera: Curculionidae) foram observados associados a árvores de ipês em Brasília, Brasil, em 2019. Para contribuir com informações a respeito de seus hábitos e os danos causados, foram avaliadas 15 árvores (Handroanthus impetiginosus $=7$, H. roseoalbus $=4$, and Tabebuia rosea $=$ 4), sendo capturados 31 indivíduos de $C$. latruncularius, frequentemente dentro ou próximos aos enrolamentos foliares causados pelo psilídeo Trioza tabebuiae Burckhardt \& Santana (Hemiptera: Triozidae). Os danos causados por C. latruncularius são injúrias nas bordas das folhas de maneira irregular. Esse é o primeiro relato de ocorrência desse besouro em ipês.
\end{abstract}

Tree planting in urban areas is importantly increasing due to its numerous benefits, including quality of life, reduction of environmental impacts and of pollution (Spirn, 1995; Lima \& Silva Junior, 2010). Trumpet tree is the common name given to a wide range of plants (trees and/or shrubs) of the genera Handroanthus, Tecoma and Tabebuia (Bignoniaceae), due to the shape of its showy flowers of different colors (yellow, white, pink and purple). The primary reason for choosing this species for urban landscaping is their lush flowering and colors variety. Therefore, they are planted in many Brazilian cities. In Brasilia, Brazilian Federal District, trumpet trees (Tabebuia aurea (Silva Manso) Benth. \& Hook. f.ex S. Moore, T. rosea (Bertoloni) A.P. de Candolle, Handroanthus chrysotrichus (Mart. ex DC.) Mattos, H. heptaphyllus (Vell.) Mattos, H. impetiginosus 
(Mart. ex DC.) Mattos, H. ochraceus (Cham.) Mattos, $H$. roseoalbus (Ridl.) Mattos and $H$. serratifolius (Vahl) S. O. Grose) are some of the most abundant planted species and can be found all over the places mainly throughout the Plano Piloto region (Kurihara et al., 2005; Silva Junior \& Costa e Lima, 2010).

Several insects have been reported associated with trumpet trees, including potentially harmful insects. Silva et al. (1968) mentioned about 15 different species of insects on trumpet trees. One of the main pests is the psyllid Trioza tabebuiae Burckhardt \& Santana 2001 (Hemiptera: Triozidae), which causes leaf rolling gals (Santana \& Burckhardt, 2001). Santana et al. (2005) described several insects associated with the leaf rolls gals caused by this psyllid, among them, Cydianerus bohemani Boheman, 1840 (Coleoptera: Curculionidae).

Cydianerus is a genus with 12 species described for the Americas (Cydianerus..., 2020). Six species of this genus are cited for Brazil: Cydianerus araneiformis (Dalman, 1833), C. bifasciatus Hustache, 1926, C. bohemani Boheman, 1840, C. latruncularius (Perty, 1832), C. ornatus (Pascoe, 1881) and C. virescens Lucas, 1857 (Vanin et al., 2020).

The objective of this study was to register the occurrence of C. latruncularius (Coleoptera: Curculionidae) in $H$. impetiginosus, $H$. roseoalbus and $T$. rosea in Brasilia, Brazil and to contribute with information about their habits and the damage they cause to the evaluated plants.

The work was carried out from October to December 2019. Fifteen trumpet trees ( $H$. impetiginosus $=7, H$. roseoalbus $=4$, and $T$. rosea $=4$ ) of different ages and sizes were inspected randomly. The trees' species was confirmed in the field by the first author, following Silva Júnior \& Costa e Lima (2010). In each plant, five leaves were evaluated for the presence of folding caused by the psyllid T. tabebuiae, occurrence of $C$. latruncularius associated with the folding, and the damage caused by this beetle. The species was confirmed by Professor Dr. Sergio Antônio Vanin of the Department of Zoology, Institute of Biosciences, University of São Paulo (USP).

In total, 31 individuals of $C$. latruncularius were captured on the 15 evaluated plants, with an average of two individuals per plant (minimum 0, maximum 6). Out of 15 plants, 11 had at least one specimen of $C$. latruncularius and 7 had leaf folding; thus, beetles were also found on plants without symptoms of rolling $(n=4)$. On the remaining 4 plants where no beetles were found, psyllid attack was also not observed $(H$. roseoalbus $=3$ and $T$. rosea $=1$ ).

Most of the C. latruncularius (17 of the 31 captured) beetles were found in or near the rolls caused by $T$. tabebuiae, possibly for shelter and protection. Some beetles were observed feeding on the leaves.

The damages caused by $C$. latruncularius on the trumpet trees leaves were typical of phytophagous beetles, with injuries at the edges of the leaves in an irregular pattern (Figure 1), unlike leafcutter ants, which cut the leaves into a half-moon shape (Matte et al., 2016). Some leaves of the sampled plants were completely damaged by the beetles and on a single leaflet up to three weevils were found.

C. latruncularius is a short-beaked weevil from the subfamily Entiminae, measuring approximately $1.5 \mathrm{~cm}$ long, with a predominantly white color on the ventral surface, black spots on the dorsal part of the thorax and elytra (Figure 1). The pronotum is granular, elytra smooth, not tuberculate-spiny (Vaurie, 1951).

In Brazil, C. latruncularius was recorded in the Federal District (Brasilia), Goiás (Goiânia), and São Paulo (Pirassununga, São Carlos and Franca) (Cydianerus..., 2020) without reference of the host plant.

Regueira et al. (2020) analyzed the shape variation in different $C$. latruncularius populations from Caatinga, Cerrado, Atlantic rainforest and Amazonian forest. They found variations among populations in different structures, especially in the pronotum, and concluded that this variation is influenced by sex and the environment.

Cydianerus bohemani is a harmful insect to trumpet trees; however, the damage caused by this insect normally is mild, despite the large populations found (Carvalho, 2003). Individuals of $C$. bohemani were observed by Santana et al. (2005) in association with the rolling leaf galls of trumpet trees in the region of Curitiba, Paraná State, however, the damage caused by this species was not characterized. Adults of C. bohemani were also found in Colombo, Paraná State feeding on Handroanthus alba (Figure 2). Cydianerus bohemani can be distinguished from $C$. latruncularius because of its slightly brown color. We compared this two species, because they both occur in Handroanthus spp.

This is the first record of C. latruncularius feeding on trumpet trees leaves, suggesting these trees are a host for this insect. Although the adults of $C$. latruncularius are frequently found on trumpet trees leaves, their damage is mild, as observed by Carvalho (2003), for C. bohemani. 

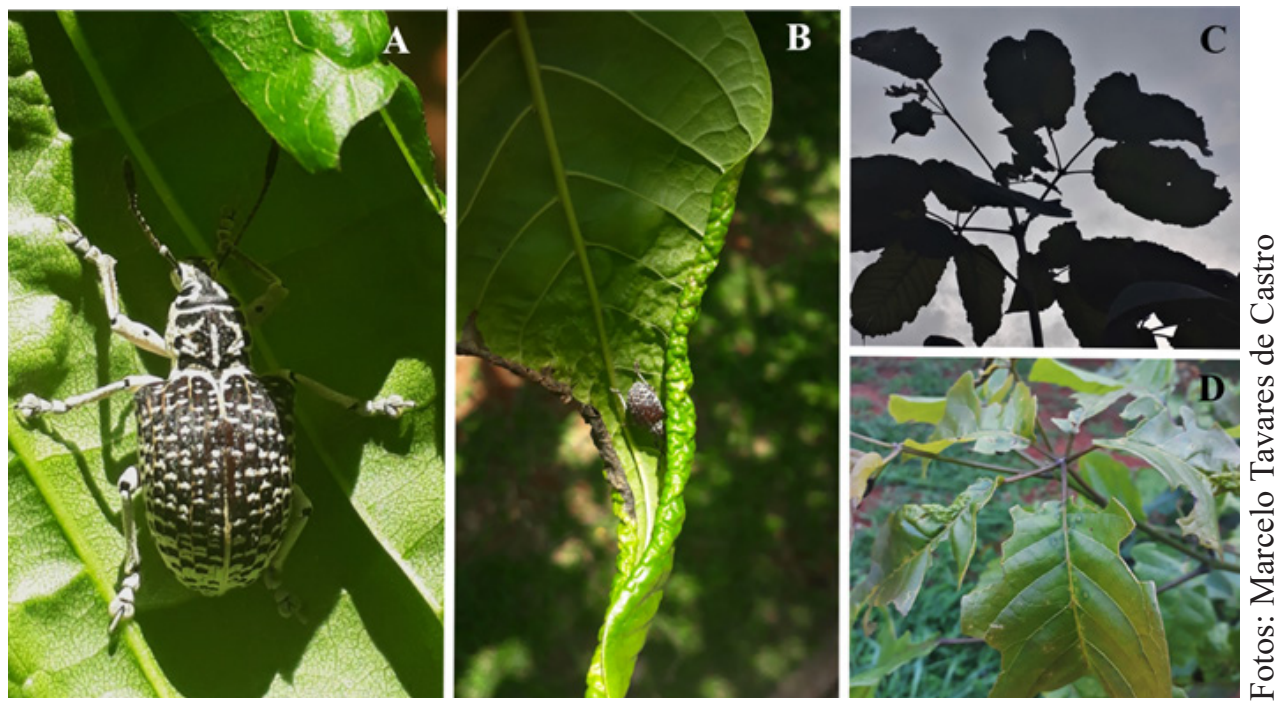

Figure 1. Cydianerus latruncularius on trumpet trees in Brasilia, Brazil. A - C. latruncularius trumpet trees leaflet. B - C. latruncularius inside a trumpet trees leaflet with folding caused by the psyllid Trioza tabebuiae. C and D - Leaves damaged by C. latruncularius.
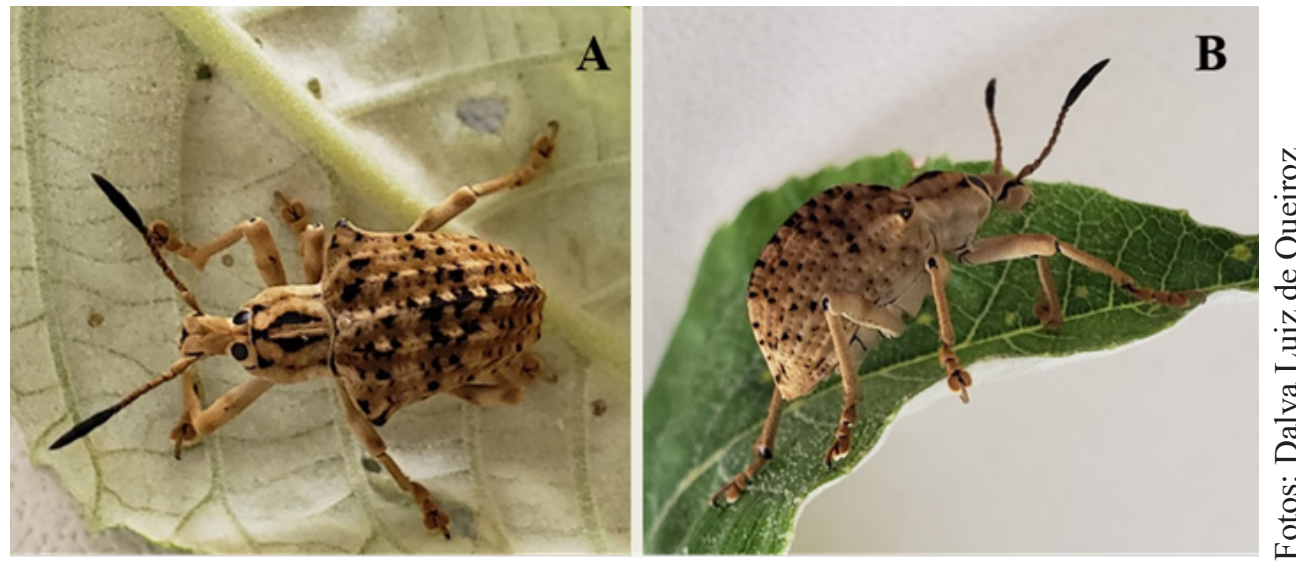

Figure 2. A and B - Cydianerus bohemani on trumpet trees (Handroanthus spp.) in Colombo, Paraná State, Brazil.

\section{Conclusions}

The beetle Cydianerus latruncularius was found damaging leaves of trumpet trees (H. impetiginosus, $H$. roseoalbus, and T. rosea) in Brasilia, Federal District, Brazil. Most of $C$. latruncularius were captured inside or close to the rolled leaves caused by the psyllid Trioza tabebuiae. This is the first recorded occurrence of $C$. latruncularius in Handroanthus and Tabebuia.

\section{Acknowledgements}

We are very grateful for Professor Dr. Sergio Antônio Vanin of the Department of Zoology, Institute of Biosciences, University of São Paulo, for identifying the insects. We would like to thank Dr. Christoph Germann, Kurator Käfersammlung Frey, Naturhistorisches Museum Basel, for helping with the literature. We also would like to thank Flávia Queiroz Sant'Anna for reviewing the English for this manuscript. 


\section{References}

Carvalho, P. E. R. Espécies arbóreas brasileiras. Brasília, DF: Embrapa Informação Tecnológica; Colombo: Embrapa Florestas, 2003. v. 1, 1039 p.

Cydianerus Schoenherr, 1840. GBIF Backbone Taxonomy: GBIF Secretariat, 2019. Checklist dataset: https://doi.org/10.15468/39omei. Acess on: Jan. 1, 2020.

Kurihara, D. L. et al. Levantamento da arborização do Campus da Universidade de Brasília, Cerne, v. 11, p. 127-136, 2005.

Lima, R. M. C. \& Silva Junior, M. C. Inventário da arborização urbana implantada na década de 60, no Plano Piloto, Brasília, DF. Revista Brasileira de Arborização Urbana, v. 5, n. 4, p. 110-127, 2010. http://dx.doi.org/10.5380/revsbau.v5i4.66321.

Matte, W. D. et al. Primeiro registro de Atta sexdens rubropilosa Forel, 1908 (Hymenoptera: Formicidae) atacando noni (Morinda citrifolia L.) em Colorado do Oeste (RO), Brasil. Arquivos do Instituto Biológico, v. 83, p. 1-4, 2016. https://doi.org/10.1590/18081657000722015 .

Regueira, J. C. S. et al. Shape variation of Cydianerus latruncularius (Coleoptera, Curculionidae) across biomes and sexes. Zoologischer Anzeiger, v. 289, p. 96-107, 2020.
Santana, D. L. Q. \& Burckhardt, D. A new triozid pest (Hemiptera, Psylloidea, Triozidae) on ornamental Trumpet Trees (Tabebuia spp., Bignoniaceae) in Brazil. Revue Suisse De Zoologie, v. 108, n. 3, p. 541-550, 2001.

Santana, D. L. Q. et al. Insetos associados ao enrolamento foliar de Tabebuia spp. em viveiros e na arborização de Curitiba. Boletim de Pesquisa Florestal, n. 50, p. 117-126, 2005.

Silva, A. G. A. et al. Quarto catálogo dos insetos que vivem nas plantas do Brasil: seus parasitos e predadores. Rio de Janeiro: Ministério da Agricultura, Laboratório Central de Patologia Vegetal, 1967-1968. 2 v. em 4 t.

Silva Júnior, M. C \& Costa e Lima, R. M. 100 árvores urbanas: Brasília: guia de campo. Brasilia, DF: Rede de Sementes do Cerrado, 2010. 280 p.

Spirn, A. W. O jardim de granito: a natureza no desenho da cidade. São Paulo: EDUSP, 1995. 329 p.

Vanin S. A. et al. Curculionidae. In: CATÁLOGO taxonômico da fauna do Brasil. PNUD. 2020. Avaliable from: http://fauna.jbrj.gov. br/fauna/faunadobrasil/5535. Acess on: Jan. 8, 2020.

Vaurie, P. Revision of the genus Entimus with notes on the genera Entimini (Coleoptera: Curculionidae). Revista Chilena de Entomología, v. 1, p. 147-170, 1951. 